\title{
NAFKAH ANAK KANDUNG YANG TERABAIKAN \\ SETELAH IBUNYA MENIKAH LAGI \\ (Studi Kasus Warga RT. 25-26 Kelurahan Teritip Balikpapan Timur)
}

\author{
Miftahul Jannah \\ STIS Hidayatullah Balikpapan \\ miftahuljannah.malewa@gmail.com \\ Andi Evi Mardiva \\ STIS Hidayatullah Balikpapan \\ Andievi334@gmail.com
}

\begin{abstract}
Abstrak
Nafkah anak kandung merupakan kewajiban seorang ayah, namun tidak semua ayah pada RT. 25-26 memberikan nafkah kepada anaknya karena adanya faktor di antaranya setelah ibunya menikah lagi. Al-Quran dan sunah telah menjelaskan bahwa ayah wajib memberikan nafkah kepada anaknya karena sudah menjadi kewajibannya sebagai seorang ayah, sama halnya dengan pendapat para ulama bahwa seorang ayah wajib memberikan nafkah yang menjadi tanggungannya. Penelitian ini akan mengungkap bagaimana tinjauan hukum Islam terhadap nafkah anak kandung setelah ibunya menikah lagi.
\end{abstract}

Keywords: kewajiban ayah, tanggungan, keluarga

\section{A. Latar Belakang Masalah}

Pernikahanlah yang menyebabkan sunah keserasian laki-laki dan perempuan tersusun dalam kerangka yang bijak dan manusiawi. Fitrah kemanusiaan berupa ketertarikan lawan jenis tidak akan bisa dibunuh atau diganggu gugat dengan cara apa pun. ${ }^{1}$

Mengenai hakikat perkawinan itu sendiri, Kompilasi Hukum Islam di Indonesia Bab II pasal 2 menyebutkan sebagai berikut: "Perkawinan hukum Islam, yaitu akad yang sangat kuat (misaaqan galiizha) untuk menaati perintah Allah dan melaksanakannya merupakan ibadah". Kemudian disebutkan dalam pasal 3, "Perkawinan bertujuan untuk mewujudkan kehidupan rumah tangga yang sakinah mawaddah dan rahmah".2

Allah swt berfirman di dalam Q.S An-Nahl [16] : 72

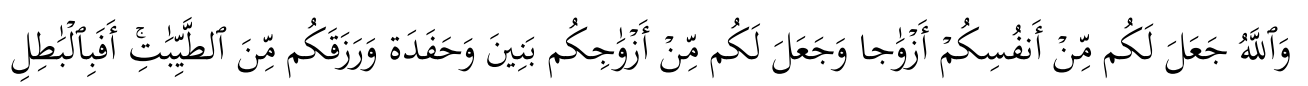

\footnotetext{
${ }^{1}$ Cahyadi Takariawan, Di Jalan Dakwah Aku Menikah, (Solo: Era Intermedia, 2006) xiv.

${ }^{2}$ Undang-Undang Kompilasi Hukum Islam, (Bandung: Fokusindo Mandiri, 2013) 9.
} 


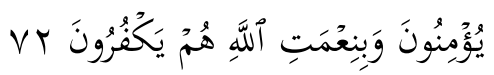

Ibnu Katsir di dalam tafsirnya menjelaskan bahwa pada ayat di atas Allah swt menceritakan berbagai macam nikmat-Nya yang telah Dia karuniakan kepada hamba-hamba-Nya, yaitu Dia menjadikan bagi mereka istri-istri dari jenis dan sosok mereka sendiri. Seandainya Dia memberikan istri dari jenis lain, niscaya tidak akan terwujud keharmonisan, cinta dan kasih sayang. Tetapi berkat kasih sayang-Nya, Dia menciptakan manusia terdiri atas laki-laki dan perempuan yang berpasang-pasangan. Kemudian Allah swt menciptakan anak dan cucu dari perkawinan mereka. ${ }^{3}$

Langgengnya kehidupan pernikahan merupakan suatu tujuan yang sangat diinginkan oleh manusia. Adakalanya dalam pernikahan timbul berbagai riak masalah dan konflik antara suami istri yang tak jarang akhirnya berujung pada perceraian.

Perceraian merupakan jalan terakhir yang boleh ditempuh dalam perkawinan. Perceraian dalam Islam merupakan perbuatan halal yang dibenci oleh Allah. ${ }^{4}$ Ketika terjadi perceraian dan ibunya menikah lagi, hubungan antara anak dan orang tua tidak akan pernah putus, sekalipun berpisah karena perceraian kedua orang tuanya dan ibunya menikah lagi.

Kelahiran anak sebagai peristiwa hukum yang terjadi karena hubungan perkawinan membawa konsekuensi hukum berupa hak dan kewajiban timbal balik antara orang tua dan anak. Anak mempunyai hak yang harus dipenuhi oleh orang tua, seperti pemenuhan kebutuhan materiil untuk biaya kehidupan anak, pendidikan anak serta kasih sayang dari orang tua.

Menurut Mazhab Maliki seorang ayah berkewajiban memberikan nafkah kepada anaknya. Jadi, nafkah itu wajib diberikan untuk anak laki-laki, maupun perempuan. Seseorang sudah dianggap melakukan dosa jika tidak memberikan nafkah pada orang-orang yang menjadi tanggungannya. ${ }^{5}$

\footnotetext{
${ }^{3}$ Abdullah bin Muhammad bin Abdurrahman Alu Syaikh, Tafsir Ibnu Katsir, trans, M. Abdul Ghoffar, (Jakarta: Pustaka Imam Asy-syafi'I, 2008). 211

${ }^{4}$ Bahay al-Khauli, Islam dan Persoalan Wanita Modern (Solo, CV. Ramadhani, 1988) 126

${ }^{5}$ Wahbah Az-Zuhaili, Wa Adillatuhu, jilid 10, trans. Abdul Hayyie al-Kattani, et.al. Fiqih sunnah Islam, (Jakarta: Gema Insani, 2011) 95.
} 
Wajibnya memberi nafkah kepada anak yang masih kecil adalah firman Allah swt di dalam Q.S. Al-Baqarah [2] : 233

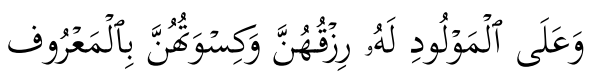

Artinya, "Dan kewajiban ayah memberi makan dan pakaian kepada para ibu dengan cara makruf seseorang tidak dibebani lebih dari kesanggupannya."

Rasulullah saw bersabda,

$$
\text { كانت له صدقة (رواه البخاري) } 6 \text { كسعود البدري رضي الله عنه : عن النبي صلى عليه و سلم قال: إن المسلم إذ أنفق على أهله نفقة وهو يحتسبها، }
$$

“Dari Abu Mas'ud Al Badri a, dari Nabi n beliau bersabda, sesungguhnya jika seorang muslim memberi nafkah untuk keluarganya karena Allah, maka nafkah tersebut bernilai sedekah baginya."

Ketika terjadi perceraian kemudian istri menikah lagi maka istri tidak wajib dinafkahi oleh mantan suaminya. Namun hak nafkah bagi anak tidak putus, sehingga ayah tetap berkewajiban menanggung semua kebutuhan anak, sekalipun anak itu tinggal bersama mantan istrinya.

Selain orang tua merasa tidak cocok lagi dan memutuskan berpisah, ada beberapa hal yang menjadi penyebab orang tua bercerai, di antaranya adalah faktor ekonomi maupun adanya pihak ketiga dalam rumah tangga. Seperti manusia secara keseluruhan yang memiliki hak asasi manusia, seorang anak juga memiliki hak tersendiri yakni hak mendapatkan nafkah dengan tujuan anak dapat tumbuh dan berkembang secara sempurna di dalam lingkungan keluarga yang utuh.

Dalam hal ini, baik Undang-Undang No.1 Tahun 1974 tentang Hukum Perkawinan maupun Instruksi Presiden No.1 Tahun 1991 Tentang Kompilasi Hukum Islam dengan tegas mengatur tentang kewajiban orang tua terhadap biaya nafkah anak setelah terjadinya perceraian yang pada hakikatnya

${ }^{6}$ Abi Abdullah Muhammad ibnu Ismail al-Bukhari, al-Jami’ Ashih, Juz III, (Qohirah: alMaktabah as-Salafiyyah, 1400H), no. 424 
membebankan kewajiban itu kepada orang tua laki-laki (ayah).

Di antaranya terdapat di dalam Undang-undang No. 1 Tahun 1974, pasal $45(1,2)$ menjelaskan bahwa: "Kedua orang tua wajib memelihara dan mendidik anak-anak mereka sebaik-baiknya". Dan Kewajiban orang tua yang dimaksud pada pasal (1) pasal ini berlaku sampai anak itu kawin atau berdiri sendiri, kewajiban mana berlaku terus meskipun perkawinan antara kedua orang tuanya putus. Di dalam Kompilasi Hukum Islam pasal 149 (d) menjelaskan bahwa bilamana perkawinan putus, maka bekas suami wajib memberikan biaya hadhanah untuk anak-anaknya yang belum mencapai umur 21 tahun.

Hal ini dipertegas dalam Kompilasi Hukum Islam pasal 105 dalam hal terjadinya perceraian bagian (c) menegaskan bahwa "Biaya pemeliharaan ditanggung oleh ayahnya".7 Adapun pasal 98 ayat (1) tentang pemeliharaan anak bahwa, "Batas usia anak yang mampu berdiri sendiri atau dewasa adalah 21 tahun, sepanjang anak tersebut tidak bercacat fisik maupun mental atau belum pernah melangsungkan perkawinan. ${ }^{8}$

Empat Imam mazhab memaparkan pendapatnya dalam kondisi jika ayah miskin. Imam Mālik menyatakan seorang individu hanya berkewajiban memberi nafkah kepada orang tua dan anak kandung. Imam Syafi'i mengatakan seoranng anak/ cucu dibebani memberi nafkah kepada bapak atau kakeknya dan seterusnya ke atas (atau ke bawah) (konsep 'awlad 'aba' atau furu' dan 'ușūl). Abu Ḥanifah mengatakan seorang individu (kerabat) dibebani nafkah kepada kerabat lainnya berdasarkan muharramiyah (walaupun bukan kerabat dari sisi aulad).

Yang dimaksud Abu Ḥanifah kerabat dari ayah, seperti kakak ayah, adik ayah, bapak ayah juga berkewajiban dalam membantu memberi nafkah kepada anak tersebut walaupun sudah terjadi perceraian. Ạ̣mad ibn Ḥanbal mengatakan seorang individu (kerabat) yang cukup dekat kekerabatannya dengan individu lain terkait warisan bagi kerabat yang membutuhkan termasuk qarabat al-awlad. Ahmad Ibn Hambal menjelaskan bahwa

\footnotetext{
${ }^{7}$ Undang-Undang Kompilasi Hukum Islam, (Bandung: Fokusindo Mandiri, 2013). 42.

${ }^{8}$ Ibid, 40.
} 
kewajiban nafkah juga dibebankan kepada kerabat dari ayah, jika ayah tidak mampu memberi nafkah kepada anak.

Masih banyak orang tua laki-laki (ayah) setelah perceraian tidak melaksanakan kewajibannya menafkahi anaknya. Hal ini menjadi salah satu faktor ketidakberuntungan anak dalam proses kehidupan dan perkembangannya baik dilihat dari sisi rohani maupun jasmani berupa pemenuhan kebutuhan hidup sehari-hari dan pendidikan yang layak.

Kadang kala nafkah bagi seorang anak itu terlalaikan terlebih jika anak tersebut tinggal bersama ibunya. Hal inilah yang terjadi pada beberapa pasangan yang istrinya menikah lagi. Realita ini terjadi di RT. 25-26 Kelurahan Teritip Balikpapan Timur.

Peneliti menemukan enam kasus di RT. 25-26 Kelurahan Teritip Balikpapan Timur. Hal ini dilakukan bukan berdasarkan ketidaktahuan mereka mengenai nafkah anak, melainkan mantan istrinya telah menikah lagi. Melihat fenomena tersebut peneliti tertarik untuk mengkaji nafkah anak kandung setelah ibunya menikah lagi dalam tinjauan Hukum Islam.

\section{A. Jenis Penelitian}

Penelitian ini menggunakan metode penelitian lapangan (Field research). Sifat penelitian yang digunakan dalam penelitian ini adalah deskriptif analitik yaitu dengan memaparkan dan menganalisis bagaimana nafkah anak kandung yang berada di RT. 25-26 Kelurahan Teritip Balikpapan Timur terhadap anak yang ibunya menikah lagi.

Penelitian ini dilakukan di RT. 25-26 Kelurahan Teritip Balikpapan Timur. peneliti juga melihat bahwa yang bertempat tinggal di RT ini orang yang memahami syariat, tetapi dalam hal memberi nafkah kepada anak kandung, terdapat permasalahan.

Teknik pengumpulan data yang digunakan dalam penelitian ini antara lain menggunakan metode-metode yaitu; Observasi; Wawancara; Studi Kepustakaan; Dokumentasi. Data yang dicari dalam penelitian ini adalah; Identitas responden yang meliputi nama, umur, pendidikan, pekerjaan, dan alamat; Bagaimana dasar hukum nafkah anak setelah ibunya nikah lagi ; Gambaran nafkah anak setelah ibunya nikah lagi; Apa yang menjadi alasan bagi ayah yang tidak memberikan nafkah kepada anaknya setelah ibunya 
nikah lagi. Sumber data yang digunakan dalam penelitian ini adalah: Data Primer yaitu data yang langsung memberikan data kepada pengumpul data, diperoleh secara langsung melalui wawancara dan pengamatan, yang termaksud data primer adalah: Responden yaitu ibu kandung. Data Sekunder: data sekunder adalah sumber data yang tidak langsung memberikan data kepada pengumpul data, misalnya data yang dikumpulkan untuk mendukung dan melengkapi data primer yang berhubungan dengan masalah penelitian. Data tersebut mencangkup dokumen-dokumen resmi RT 25 dan 26, juga berupa buku, majalah, artikel, hasil penelitian sebelumnya, atau media lain yang menunjang sebagai landasan teori.

\section{B. Hak dan Kewajiban Orang Tua Terhadap Anaknya}

\section{Definisi Nafkah}

Secara bahasa an-Nafaqah (النفقة) diambil dari al-Infaq (إلانفاق). Bermakna mengeluarkan dan menghabiskan, namun infak hanya dipakai untuk kebaikan secara syariat. Nafkah menurut istilah fuqaha adalah beban yang dikeluarkan seseorang terhadap orang yang wajib ia nafkahi berupa roti, lauk pauk, pakaian, tempat tinggal. ${ }^{9}$ Nafkah adalah mencukupi kebutuhan orang-orang yang menjadi tanggung jawabnya dengan cara yang baik, mencakup makanan, pakaian, dan tempat tinggal. ${ }^{10}$

Berdasarkan pada Kamus Besar Bahasa Indonesia, nafkah adalah pendapatan suami yang wajib diberikan kepada istri. ${ }^{11}$ Menurut ulama mazhab Hanafi, nafkah adalah melimpahkan kepada sesuatu dengan hal yang menyebabkan kelanggengan. Ulama mazhab Malik ibnu `Arafah al-Maliki berkata, Nafkah adalah sesuatu yang menjadi penopang standar untuk kehidupan manusia tanpa ada unsur pemborosan. ${ }^{12}$ Nafkah adalah

${ }^{9}$ Abdurrahman Al-Juzairi, Fiqih `ala al-Mazahib al-Arba`ah, Juz IV, (Beirut: Dar Fikr, 1406 H), h. 553.

${ }^{10}$ Abu Bakar Jabir Al-Jaza iri, Minhajul Muslim, (Beirut: Daru al-Fikr, 1419 H), h. 340.

${ }^{11}$ Tim Redaksi Kamus Besar Bahasa Indonesia, Kamus Besar Bahasa Indonesia, (Jakarta: PT Gramedia Pustaka Utama, 2008), h. 947.

12 Abdurrahman Al-Jaza'iri, Fiqih `Ala Mażahib al- Arba`ah, Juz IV, (Mesir: AlMaktabah Al-Tijariyyah Al Kubro, 1969 H), h. 549. 
pendapatan suami yang wajib diberikan kepada istri. ${ }^{13}$ Kompilasi Hukum Islam juga menjelaskan tentang nafkah merupakan kewajiban suami, terdapat pada pasal 80 ayat 4 yaitu:

a. Nafkah pakaian dan tempat kediaman istri.

b. Biaya rumah tangga, biaya perawatan, serta pengobatan bagi istri dan anak.

c. Biaya pendidikan bagi anak. ${ }^{14}$

\section{Dasar Hukum Nafkah}

\section{a. Dalil dari al-Qur'an}

Hukum nafkah tercantum dalam beberapa ayat dalam al-Qur'an yang menjadi dasar nafkah secara umum, terkhusus kewajiban-kewajiban yang terkait dengan pemberian nafkah di sini yaitu semua macam belanja yang dikeluarkan oleh suami untuk memenuhi keperluan istri dan anakanaknya. ${ }^{15}$

Ayat-ayat yang menunjukkan tentang nafkah seseorang yang menjadi tanggung jawabnya, antara lain Allah swt berfirman dalam Q.S al-Baqarah [2] : 233,

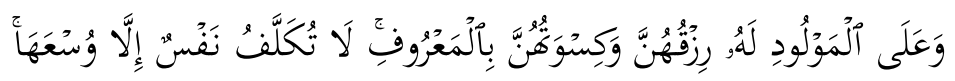

Ayat tersebut telah menegaskan bahwa ayah berkewajiban menanggung segala kebutuhan makan anak dan pakaian ibu yang menyusui anaknya sekalipun telah diceraikan oleh ayah anaknya, jika mantan istri yang masih menyusui anaknya wajib untuk diberikan nafkah.

Allah swt berfirman dalam Q.S An-Nisa` [4] : 5

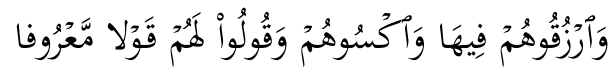

Allah swt juga berfirman dalam Q.S ath-Thalaq [65] : 7

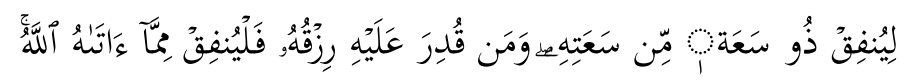

${ }^{13}$ Tim Redaksi Kamus Besar Bahasa Indonesia, Kamus Besar Bahasa Indonesia, (Jakarta: PT Gramedia Pustaka Utama, 2008), h. 947.

${ }^{14}$ Suparman, Kompilasi Hukum Islam, (Jakarta: Gaya Media Pratama, 2001), h. 240. 2000), 19

${ }^{15}$ Muhammad Thalib, Ketentuan Nafkah Istri dan Anak, (Bandung: Irsyad Baitus Salam, 
Ayat tersebut menunjukkan kewajiban suami untuk memberi nafkah kepada istrinya, walaupun suami disempitkan rezekinya tetap harus memberikan nafkah yang diberikan Allah swt kepadanya. Allah swt kelak akan memberikan kelapangan sesudah kesempitan.

Allah swt juga berfirman tentang kadar nafkah sesuai dengan kemampuan seorang ayah dalam Q.S al-Baqarah [2] : 286,

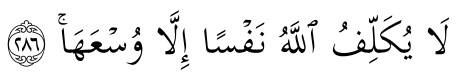

\section{b. Dalil dari Sunnah}

Demikian juga dengan hadis-hadis Rasulullah saw yang mewajibkan nafkah atas seorang ayah terhadap keluarganya. Adapun landasan wajibnya memberikan nafkah yang bersumber dari hadis Rasulullah saw,,, sebagaimana diriwayatkan oleh Jabir a berkata :

$$
\text { و كن جابر رضى الله عنه عن النى صلى الله عليه و سلم في حديث الحج بطوله قال في ذكر النساء : ولهن عليكم رزقهن }
$$

“Dari Jabir a, Nabi n bersabda pada waktu melaksanakan ibadah haji, beliau mengingatkan kepada para suami tentang perkara seorang perempuan, beliau bersabda: "Mereka mempunyai hak rezeki dan pakaian atas kalian dengan cara yang ma'ruf."

Memberi nafkah hukumnya wajib, seorang suami jika tidak memberi nafkah istrinya, berarti telah melanggar perintah Allah. Sabda Rasulullah saw:

$$
\text { عمّن عبملك قعتله بن عمرو بن العاص رضي الله عنهما قال: قال رسول الله صلى الله عليه و سلم: كفى بالمرء إثما أن يجبس }
$$

"Dari Abdullah bin 'Amr bin al 'ash a, ia berkata, Rasulullah saw, bersabda: "Cukuplah dosa seseorang karena tidak memberi makan orang yang menjadi tanggungannya."

Hadis Rasulullah saw tentang nafkah bernilai sedekah yang

\footnotetext{
${ }^{16}$ Muslim bin al-hajjaj Abu al-Husaini al-Qusyairi an-Naisaburi, Sahih Muslim, (Beirut: Dar Ihya at-Turats al-Araby, $\mathrm{tt}$ ), no. 886

${ }^{17}$ Abu al-Husaini Muslim bin al-hajaj ibnu Muslim al-Qusyairi an-Naisaburi, al-Jami' assahih, (Beirut: Dar Ihya at-Turats al-Araby, tt), no. 78
} 
diriwayatkan oleh Mas'ud Al Badri a:

$$
\text { كانت له صدقة (رواه البخاري) } 18
$$

“Dari Abu Mas’ud Al Badri a, dari Nabi n beliau bersabda, sesungguhnya jika seorang muslim memberi nafkah untuk keluarganya karena Allah, maka nafkah tersebut bernilai sedekah baginya.

\section{c. Pendapat Para Ulama}

Para Ulama telah bersepakat tentang kewajiban seorang ayah dalam memberi nafkah kepada anaknya jika telah terpenuhi syarat-syarat yang mewajibkannya.

Menurut mazhab Hambali, ayah masih berkewajiban memberi nafkah kepada anaknya yang sudah dewasa, apabila dia miskin, walaupun tidak cacat fisik atau mental, nafkah itu wajib juga diberikan kepada semua keluarga yang masih saling mewarisi, begitu juga pendapat Imam Syafi'i keluarga yang wajib diberi nafkah meliputi keluarga dari garis keturunan ke bawah (furu'), yaitu anak, cucu dan seterusnya ke bawah dan keluarga dari garis keturunan ke atas yaitu ayah, ibu, kakek, nenek dan seterusnya ke atas. $^{19}$

Menurut mazhab Maliki, nafkah hanya wajib bagi kedua orang tuanya dan anak-anaknya yang merupakan keturunan langsung, dan tidak mencakup orang lain seperti halnya cucu dan nenek. Nafkah anak perempuan yang telah besar tetap ditanggung oleh ayahnya sampai anak tersebut menikah. ${ }^{20}$

Menurut mazhab Hanafi, wajib hukumnya memberi nafkah kepada kerabat mahram karena pernikahan. Jika kerabat dekat namun tidak mahram maka tidak wajib dinafkahi.

${ }^{18}$ Abi Abdullah Muhammad ibnu Ismail al-Bukhari, al-Jami’ Ashih, Juz III, (Qohirah: alMaktabah as-Salafiyyah, 1400H),no. 424

${ }^{19}$ Wahbah Az-Zuhaili, Fiqih sunnah Islam Wa Adillatuhu, jilid 10, trans. Abdul Hayyie al-Kattani, et.al. (Jakarta: Gema Insani, 2011), 96.

${ }^{20}$ Ibid., 95 


\section{d. Kompilasi Hukum Islam}

Kompilasi hukum Islam menjelaskan bahwa nafkah merupakan kewajiban seorang ayah. Hal ini ditegaskan dalam kompilasi Hukum Islam di Indonesia Bab VIII pasal 41 bagian (b) menyebutkan bahwa "Bapak yang bertanggung-jawab atas semua biaya pemeliharaan dan pendidikan yang diperlukan anak itu, bilamana bapak dalam kenyataan tidak dapat memenuhi kewajiban tersebut, pengadilan dapat menentukan bahwa ibu ikut memikul biaya tersebut". ${ }^{21}$

Hak mendapat kehidupan bagi anak dalam Islam merupakan hak anak yang tidak boleh diganggu. Dipertegas dalam Kompilasi Hukum Islam pasal 105 dalam hal terjadinya perceraian bagian (c) menegaskan bahwa "Biaya pemeliharaan ditanggung oleh ayahnya". ${ }^{22}$ Adapun pasal 98 ayat (1) tentang pemeliharaan anak bahwa, "Batas usia anak yang mampu berdiri sendiri atau dewasa adalah 21 tahun, sepanjang anak tersebut tidak bercacat fisik maupun mental atau belum pernah melangsungkan perkawinan. ${ }^{23}$

\section{Hak}

Hak adalah segala sesuatu yang harus di dapatkan oleh setiap orang yang telah ada sejak lahir. Dalam Kamus Bahasa Indonesia hak memiliki pengertian tentang sesuatu hal yang benar, milik, kepunyaan, kewenangan kekuasaan untuk berbuat sesuatu, kekuasaan yang benar atas sesuatu atau untuk menuntut sesuatu, derajat atau martabat. ${ }^{24}$

\section{Kewajiban}

Kewajiban adalah suatu tindakan yang harus dilakukan seseorang sebagai bentuk tanggung jawab atas permasalahan tertentu, baik secara moral maupun hukum. Hak dan kewajiban merupakan sesuatu yang harus berjalan bersama dan seimbang. Dalam hal ini, kewajiban adalah peran yang bersifat imperatif atau harus dilaksanakan. Bila kewajiban tidak dilakukan

\footnotetext{
${ }^{21}$ Undang-Undang Kompilasi Hukum Islam, (Bandung: Fokusindo Mandiri, 2013) 108

22 Ibid., 42.

23 Ibid., 40 .

${ }^{24}$ Abu Hadian Shafiyarrahmah, Hak-Hak Anak dalam Syariat Islam, (Yogyakarta: Al-
} Manar, 2003), 6 
maka seseorang dapat dikenakan sanksi, baik secara hukum maupun sanksi sosial. 25

\section{Hak Anak Untuk Menerima Nafkah}

Hak yang harus didapat oleh seorang anak adalah mendapatkan nafkah yang cukup selagi dia masih kecil dan belum mampu untuk mencari nafkah sendiri. Nafkah terhadap anak meliputi makanan, pakaian, tempat tinggal, dan pemberian upah pembantu bila anak memang betul-betul membutuhkan pembantu. Nafkah terhadap anak wajib diberikan oleh ayahnya sekalipun dia fakir, asalkan dia mampu berusaha. Ketidakmampuan ayah bukanlah penghalang yang dapat menggugurkan kewajiban untuk memberi nafkah kepada anaknya. ${ }^{26}$

\section{Nafkah Anak Kandung}

Ayah kandung berkewajiban memberikan jaminan nafkah kepada anak kandungnya berupa makanan, pakaian, tempat tinggal, dan kebutuhankebutuhan lainnya. Orang yang paling dekat dengan anak adalah ayah dan ibunya, apabila ibu bertanggung jawab atas pengasuhan anak di rumah maka ayah bertanggung jawab mencarikan nafkah anaknya.

Pihak ayah hanya berkewajiban menafkahi anak kandungnya selama anak kandungnya dalam keadaan membutuhkan nafkah, ayah tidak wajib menafkahi anaknya yang mempunyai harta untuk membiayai dirinya sendiri. Seorang ayah yang mampu namun tidak memberikan nafkah kepada anaknya padahal anak tersebut sedang membutuhkan, dapat dipaksa oleh hakim atau dipenjarakan sampai dia bersedia menunaikan kewajibannya.

Kewajiban ayah dalam memberi nafkah terhadap anak laki-lakinya gugur apabila anak tersebut telah balig dan mampu mencari rezeki namun nafkah anak perempuan dihentikan jika dia telah menikah. Kecuali anak tersebut menderita sakit atau gila, maka nafkahnya masih menjadi tanggungan ayahnya. ${ }^{27}$

\footnotetext{
${ }^{25}$ Ibid, 7

${ }^{26}$ Ibid., 98.

${ }^{27}$ Abu Bakar Jabir al-Jaza'iri, Minhajul Muslim, trans. Kholif Mutaqin, (Jakarta: Darul Haq, 20006), 1004.
} 


\section{Jumlah Nafkah Anak}

Ulama fikih sependapat bahwa nafkah anak yang wajib diberikan adalah sesuai dengan kebutuhan pokok anak itu dan sesuai pula dengan situasi dan kondisi ayah dan anak itu. ${ }^{28}$ Jika ayah dalam kondisi kesulitan rezeki, maka dia memberikan nafkah kepada keluarganya dalam minimal yang mencukupinya berupa makanan dan lauk pauk dengan sepatutnya, serta berupa pakaian yang mencukupinya dengan mutu terendah baik pakaian untuk musim panas, maupun pakaian untuk musim dingin. ${ }^{29}$ Jika ayah dalam kondisi pertengahan, maka ayah memberikan nafkah yang lebih layak dan pakaian yang lebih bermutu dari itu. ${ }^{30}$

\section{Syarat-syarat Nafkah Anak}

Seorang ayah tidak hanya berkewajiban menafkahi seorang istri, namun ayah juga berkewajiban memberi nafkah terhadap anak kandungnya, juga para kerabatnya jika memenuhi syarat-syarat nafkah. Syarat-syarat nafkah anak yaitu:

1. Anak yang masih kecil yang belum mampu mencari nafkah sendiri. Lain halnya apabila anak itu sudah dewasa, tidak wajib lagi diberi nafkahnya. Jika anak benar-benar tidak mampu mencari sendiri karena gila dan penyakit-penyakit yang tidak memungkinkan untuk bekerja, anak tersebut tetap menjadi tanggungan ayah mereka.

2. Ayah mempunyai harta dan berkuasa memberi nafkah yang menjadi tulang punggung kehidupannya. ${ }^{31}$

3. Anak wanita yang miskin sampai dia bersuami. Apabila sudah menikah maka sang suami yang menanggung nafkahnya, jika suaminya meninggal dan tidak mendapatkan warisan nafkah yang cukup untuk hidupnya, ayahnya berkewajiban memberi nafkah kepadanya.

${ }^{28}$ M. Ali Hasan, Pedoman Hidup Berumah Tangga dalam Islam, (Jakarta: Siraja Prenada Media Group, 2006), 226 2000), 619

${ }^{29}$ Abu Bakr Jabir al-Jauzairi, Minhajul Muslim, trans. Fadli Bahri, (Jakarta: Darul Falah,

${ }^{30}$ Ibid., 438

31 Tihami, dan Sohari Sahrani, Fikih Munakahat, (Jakarta: Rajawali Pers, 2013), 169 
4. Anak yang masih menuntut ilmu walaupun sudah dewasa dan mampu mencari rezeki sendiri, ayah tetap berkewajiban memberikan nafkah. Kegiatannya menuntut ilmu jangan sampai terganggu karena mencari rezeki.

5. Anak laki-laki hingga dewasa (21 tahun).

\section{Nafkah Anak Setelah Ibunya Menikah Lagi}

seorang anak juga memiliki hak untuk hidup sehingga menjadi kewajiban orang tua memelihara, memberi nafkah, dan ilmu yang bermanfaat kepada anak hingga anak itu dewasa. Pemberian nafkah tidak ada perbedaan antara laki-laki dan perempuan. Nafkah ini berupa makanan pokok atau yang mengenyangkan yang berlaku di negeri yang bersangkutan. Ketika seorang ayah tidak memberikan nafkah kepadanya anaknya, di samping dia berdosa hal itu juga merupakan utang baginya.

Orang tua bercerai dan telah menikah lagi. Ayah yang telah mempunyai keluarga baru merasa tidak perlu bertanggung jawab terhadap anak kandungnya karena telah diasuh oleh ibu yang telah menikah lagi.

Padahal sudah jelas dalam al-Qur'an bahwa sebagai timbal balik dari melaksanakan kewajiban yang ditetapkan Allah swt terhadap ibu kepada anaknya itu, maka si ayah (meskipun telah menceraikannya) berkewajiban untuk memberikan nafkah dan pakaian kepada si ibu jika masih merawatnya dengan menyusui. Nafkah merupakan kewajiban ayah terhadap anaknya, nafkah tidak pernah gugur sekalipun harus pergi meninggalkan keluarga untuk beribadah karena kewajiban nafkah ini adalah kewajiban syariat. ${ }^{32}$

Hubungan antara anak dan orang tuanya tidak akan pernah putus, sekalipun berpisah karena perceraian kedua orang tuanya dan ibunya menikah lagi. Saat ini banyak terjadi orang tua yang mengabaikan hal ini dengan berbagai alasan dan bentuknya, tidak bertanggung jawab terhadap anak dengan tidak memberi nafkah kepada mereka.

Islam mewajibkan bapak memberi nafkah kepada anak-anak selama mereka masih lemah untuk bekerja dan berusaha. Menyia-nyiakan anak,

${ }^{32}$ Abdul Majid Mahmud Mathlub, Panduan Hukum Keluarga Sakinah, (Surakarta: Era Intermedia, 2005), 618 
meninggalkan nafkah kepada mereka, mengabaikan tanggung jawab terhadap mereka termasuk dosa-dosa besar yang tidak patut bagi seorang muslim. ${ }^{33}$ Tidak boleh ada yang mencampuri nafkah seorang ayah terhadap anaknya, nafkah adalah sebuah tanggung jawab bagi dirinya (ayah). Syariat telah mewajibkan seorang bapak memberikan nafkah kepada buah hatinya sebab itu adalah keturunannya. ${ }^{34}$

\section{Laporan Hasil Penelitian}

\section{Gambaran Umum Lokasi Penelitian Kelurahan Teritip}

Kelurahan Teritip di kecamatan Balikpapan Timur berada di wilayah paling ujung dari kota Balikpapan yang berbatasan dengan Kabupaten Kutai Kertanegara. Kondisi topografi 70\% dari luas Kelurahan Teritip merupakan daerah perbukitan dengan ketinggian 75 meter dari permukaan laut dan 25\% merupakan daerah dataran rendah yang sempit dan berada di antara perbukitan dan pesisir pantai sedangkan $5 \%$ adalah laut.

Rata-rata pertumbuhan penduduk pada periode 2016-2017 sebanyak 0,005 \% per tahun. sedangkan penduduk Kelurahan Teritip pada tahun 2016 berjumlah 13.907 jiwa, kemudian pada tahun 2017 berjumlah 14.509 jiwa, dan pertumbuhan penduduk tahun 2016-2017 sebesar 719 jiwa per tahun.

Masyarakat di RT 25 dan 26 berada di lingkungan pondok pesantren yang membuat masyarakat di wilayah ini dalam interaksinya di rekayasa mengikuti pola hidup islami.

2. Gambaran Umum Lokasi Penelitian Warga RT. 25-26 Kelurahan Teritip Kecamatan Balikpapan Timur

RT. 25-26 Kelurahan Teritip Kecamatan Balikpapan Timur secara administrasi memiliki batasan-batasan sebagai berikut:

a. Sebelah Utara : Vila Madani

${ }^{33}$ Ali Yusuf As-Subki, Fikih Keluarga, (Jakarta: Amzah, 2010), 283

${ }^{34}$ Abdul Majid Mahmud Mathlub, Panduan Hukum Keluarga Sakinah, trans. Fadlhy dan Ahmad Khotib, (Surakarta, Era Intermedia, 2005), 617 
b. Sebelah Selatan : Hj. Raden

c. Sebelah Barat : Kampung Bugis

d. Sebelah Timur : Gunung Tembak

Penduduk RT. 25-26 Kelurahan Teritip Kecamatan Balikpapan Timur tahun 2017 berjumlah 1.210 jiwa.

a. Klasifikasi Kasus Responden

\begin{tabular}{|c|c|c|}
\hline Responden & $\begin{array}{l}\text { Nafkah anak kandung setelah } \\
\text { ibunya menikah lagi (studi } \\
\text { kasus RT. 25-26 Kelurahan } \\
\text { Teritip Balikpapan Timur) }\end{array}$ & Faktor penyebab \\
\hline I.III.V.VI & $\begin{array}{l}\text { a. Nafkah yang diberikan } \\
\text { kepada anaknya tidak } \\
\text { mencukupi kebutuhan } \\
\text { anaknya }\end{array}$ & $\begin{array}{llr}\text { a. } & \text { Karena ibunya } & \text { sudah } \\
& \text { menikah lagi } & \\
\text { b. } & \text { Merasa } & \text { bukan } \\
& & \\
& \text { tanggungannya } & \text { lagi } \\
& \text { karena telah } & \text { memiliki } \\
& \text { ayah baru } & \end{array}$ \\
\hline IV & $\begin{array}{l}\text { a. Tidak pernah memberi } \\
\text { nafkah sama sekali kepada } \\
\text { anaknya setelah perceraian } \\
\text { terjadi }\end{array}$ & $\begin{array}{l}\text { a. Karena sudah tidak } \\
\text { peduli dengan anaknya } \\
\text { b. Karena ibunya telah } \\
\text { menikah lagi }\end{array}$ \\
\hline II & \begin{tabular}{|l} 
a. Nafkah anak pertama dari \\
hasil pernikahannya yang \\
pertama \\
b. \\
Nafkahnya anak yang kedua \\
dari hasil pernikahan yang \\
kedua tidak diberikan lagi
\end{tabular} & $\begin{array}{l}\text { a. Masih diberi nafkah oleh } \\
\text { bapaknya } \\
\text { b. Karena tidak bernasab } \\
\text { kepadanya dan hasil } \\
\text { pernikahan siri } \\
\text { c. Karena ibunya menikah } \\
\text { lagi }\end{array}$ \\
\hline
\end{tabular}

Kesimpulan:

Dari penyajian matriks di atas, dapat disimpulkan bahwa nafkah anak kandung setelah ibunya menikah lagi di RT. 25-26 terbagi menjadi empat kategori, yaitu Nafkah yang diberikan kepada anaknya tidak mencukupi kebutuhan anaknya karena ibunya telah menikah lagi dan merasa bahwa anak kandungnya bukan lagi menjadi tanggungannya terdapat pada kasus I, 
III, V, dan VI dan Tidak peduli juga tidak pernah memberikan nafkah sama sekali kepada anaknya setelah perceraian terjadi terdapat pada kasus IV sedangkan pada kasus II terbagi menjadi dua yaitu, Nafkah anak pertama dari hasil pernikahannya yang pertama masih terpenuhi dan Nafkah anak yang kedua dari hasil pernikahan yang kedua tidak diberikan lagi karena hasil dari pernikahan siri dan ibunya juga telah menikah lagi.

\section{E. Analisis Data}

Berdasarkan penelitian kualitatif yang peneliti lakukan di lapangan dan temuan data yang dipaparkan di atas, peneliti menemukan bahwa nafkah anak kandung setelah ibunya menikah lagi di RT. 25-26 terbagi menjadi empat kategori dan ditinjau dalam hukum Islam:

1. Menurut warga RT. 25-26 Kelurahan Teritip Balikpapan Timur yang telah bercerai dengan istrinya kemudian mempunyai anak dan istrinya menikah lagi, Nafkah yang diberikan kepada anaknya tidak mencukupi kebutuhan anaknya karena ibunya telah menikah lagi dan merasa bahwa anak kandungnya bukan lagi menjadi tanggungannya dengan alasan ini ayah dalam memberikan nafkah tidak sesuai dengan ketentuan hukum Islam.

Menurut tinjauan hukum Islam ketika terjadi perceraian antara kedua orang tuanya maka hak nafkah anaknya tidak putus dan tetap menjadi tanggung jawab ayahnya sekalipun mantan istrinya telah menikah lagi dan anaknya tinggal bersama ibunya. Nafkah menjadi tanggung jawab seorang ayah untuk memenuhi kebutuhan dasar keluarga. Kewajiban suami memberikan nafkah kepada istri dan anakanaknya merupakan perintah Allah swt .35 Menafkahi anak adalah kewajiban bagi ayah berdasarkan firman Allah swt dalam Q.S AlBaqarah [2] : 233

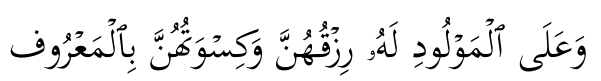

Sayyid Quthb menafsirkan ayat ini bahwa sebagai timbal balik dari melaksanakan kewajiban yang ditetapkan Allah terhadap ibu

${ }^{35}$ Sulastiningsih, Cerdas Mengelolah Keuangan Keluarga, (Yogyakarta: Pro-U Media, 
kepada anaknya itu, maka si ayah (meskipun telah menceraikannya) berkewajiban untuk memberi nafkah dan pakaian kepada si ibu secara patut dan baik. Jadi, kedua-duanya mempunyai beban dan tanggung jawab terhadap si kecil yang masih menyusu ini. Si ibu merawatnya dengan menyusui dan memeliharanya, dan si ayah harus memberi makanan dan pakaian kepada si ibu itu supaya dia dapat memelihara anaknya. Masing-masing harus menunaikan kewajibannya sesuai batas kemampuannya, Allah swt berfirman dalam Q.S. Al-Baqarah [2] : $286 .{ }^{36}$

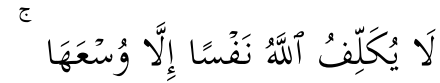

2. Ketika terjadi perceraian antara kedua orang tuanya sebagian anak tidak mendapatkan nafkah sama sekali dari ayahnya karena sang ayah sudah tidak peduli lagi dengan anaknya dan ibunya juga telah menikah lagi, mereka (ayah) menganggap nafkah anak tersebut bukan menjadi tanggungannya lagi melainkan ayah tirinya.

Menurut tinjauan hukum Islam, walaupun orang tuanya telah bercerai maka hak nafkah atas anak tidak putus dan tetap menjadi tanggung jawab seorang ayah meskipun ibunya telah menikah lagi karena anak tersebut tetap bernasab kepadanya bukan kepada ayah tirinya.

Seorang suami dalam hal memberi nafkah kepada keluarganya merupakan perkara yang wajib. Ayah kandung berkewajiban memberikan jaminan nafkah kepada anak kandungnya berupa makanan, pakaian, tempat tinggal, dan kebutuhan-kebutuhan lainnya. Orang yang paling dekat dengan anak adalah ayah dan ibunya, apabila ibu bertanggung jawab atas pengasuhan anak di rumah maka ayah bertanggung jawab mencarikan nafkah anaknya.

Pihak ayah hanya berkewajiban menafkahi anak kandungnya selama anak kandungnya dalam keadaan membutuhkan nafkah. Memberi nafkah hukumnya wajib, seorang ayah jika tidak memberi

${ }^{36}$ Sayyid Quthb, Tafsir Fi Zhilalil Qur'an, jilid 1, (Jakarta: Gema Insani, 2005) 302. 
nafkah kepada anaknya, berarti telah melanggar perintah Allah. Sabda Rasulullah n :

عن عبدالله بن عمرو بن العاص رضي الله عنهما قال: قال رسول الله صلى الله عليه و سلم:

$$
\text { كفى بالمرء إثما أن يحبس عمّن يملك قوته (رواه مسلم) }
$$

“Dari Abdullah bin 'Amr bin al 'ash a, ia berkata, Rasulullah saw, bersabda: "Cukuplah dosa seseorang karena tidak memberi makan orang yang menjadi tanggungannya".

3. Lain halnya pada kasus II, nafkah anak pertama dari hasil pernikahannya yang pertama masih terpenuhi, menurut warga yang memiliki anak tersebut. Menurut tinjauan hukum Islam pemenuhan nafkah sudah sesuai dengan syariat karena menunaikan kewajiban apa yang sudah menjadi tanggung jawabnya. Kaidah fiqhiyyah juga menerangkan bahwa:

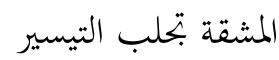

"Kesukaran itu menimbulkan adanya kemudahan"38

Maksud dari kaidah tersebut yaitu apabila seorang ayah dalam keadaan sulit dan tidak mampu untuk menafkahi anaknya, maka gugur kewajiban ayah ketika anak tersebut mampu bekerja secara mandiri.

Kewajiban ayah menafkahi anaknya tidak akan pernah gugur kecuali keadaan yang mengubahnya menjadi gugur, apabila anak fakir sudah mampu bekerja sendiri maka ayah telah gugur dalam memberikan nafkah. Batasan nafkah untuk anak perempuan itu sampai anak perempuan tersebut menikah.

عن أبي مسعود البدري رضي الله عنه : عن النبي صلى عليه و سلم قال: إن المسلم إذ

${ }^{37}$ Abu al-Husaini Muslim bin al-hajaj ibnu Muslim al-Qusyairi an-Naisaburi, al-Jami' assahih, (Beirut: Dar Ihya at-Turats al-Araby, tt), no. 78

${ }^{38}$ Nashr Farid Muhammad Washil dan Abdul Aziz Muhammad Azzam, Qawa id Fiqhiyyah, (Jakarta: Amzah, 2009), 55 


$$
\text { أنفق على أهله نفقة وهو يمتسبها، كانت له صدقة (رواه البخاري) }
$$

“Dari Abu Mas'ud Al Badri a, dari Nabi n beliau bersabda, sesungguhnya jika seorang muslim memberi nafkah untuk keluarganya karena Allah, maka nafkah tersebut bernilai sedekah baginya."

Bapak menanggung rezeki, pakaian dalam batas-batas kemampuannya. Nafkah bagi anak-anak seperti pahala bersedekah. Bertanggung jawab pada mereka, bekerja untuk mereka sebagai jalan yang aman untuk ke surga dan derajat yang utama.

4. Anak yang merupakan hasil dari pernikahan sah secara hukum Islam. Menurut warga RT. 25-26 yang memiliki anak dari hasil pernikahan siri dan pernikahannya tidak sah secara hukum negara itu tidak berhak mendapatkan nafkah dari ayahnya setelah perceraian karena anak tersebut tidak bernasab kepada ayahnya, disebabkan pernikahan kedua orang tuanya tidak sah secara hukum negara.

Menurut tinjauan hukum Islam, nafkah tetap wajib diberikan kepada anak setelah perceraian, sekalipun anak tersebut tidak sah secara hukum negara, karena pada dasarnya pernikahan yang sah secara hukum Islam yang menyebabkan anak tersebut bernasab kepada ayahnya bukan berdasarkan hukum negara.

Alasan tersebut tidak menggugurkan kewajiban ayah dalam hal memberikan nafkah kepada anaknya karena anak tersebut tetap bernasab kepadanya, para Ulama telah bersepakat tentang kewajiban seorang ayah dalam memberi nafkah kepada anaknya jika telah terpenuhi syarat-syarat yang mewajibkannya.

Menurut mazhab Hambali, ayah masih berkewajiban memberi nafkah kepada anaknya yang sudah dewasa, apabila dia miskin, walaupun tidak cacat fisik atau mental, nafkah itu wajib juga diberikan kepada semua keluarga yang masih saling mewarisi, begitu juga pendapat Imam Syafi'i keluarga yang wajib diberi nafkah meliputi keluarga dari garis keturunan ke bawah (furu'), yaitu anak, cucu dan

${ }^{39}$ Abi Abdullah Muhammad ibnu Ismail al-Bukhari, al-Jami’ Ashih, Juz III, (Qohirah: alMaktabah as-Salafiyyah, 1400H), no. 424 
seterusnya ke bawah dan keluarga dari garis keturunan ke atas yaitu ayah, ibu, kakek, nenek dan seterusnya ke atas. ${ }^{40}$

Menurut mazhab Maliki, nafkah hanya wajib bagi kedua orang tuanya dan anak-anaknya yang merupakan keturunan langsung, dan tidak mencakup orang lain seperti halnya cucu dan nenek. Nafkah anak perempuan yang telah besar tetap ditanggung oleh ayahnya sampai anak tersebut menikah. ${ }^{41}$

Menurut mazhab Hanafi, wajib hukumnya memberi nafkah kepada kerabat mahram karena pernikahan. Jika kerabat dekat namun tidak mahram maka tidak wajib dinafkahi. Nafkah adalah kewajiban seorang ayah kepada anaknya karena hubungan nasab. Seorang yang memiliki hubungan nasab selain berkewajiban menafkahi dirinya juga berkewajiban untuk menanggung kebutuhan keluarga atau anak. Hal ini karena pernikahan sah yang menyebabkan adanya hak anak terhadap ayahnya.

\section{F. Kesimpulan}

Melalui pembahasan pada bab-bab sebelumnya, mengenai nafkah anak kandung setelah ibunya menikah lagi, maka peneliti akan mengemukakan beberapa kesimpulan akhir sebagai jawaban dari permasalahan kasus yang ada dalam penelitian ini, yaitu:

Nafkah anak kandung setelah ibunya menikah lagi di RT. 25-26 terbagi menjadi empat kategori, yaitu Nafkah yang diberikan kepada anaknya tidak mencukupi kebutuhan anaknya karena ibunya telah menikah lagi dan merasa bahwa anak kandungnya bukan lagi menjadi tanggungannya terdapat pada kasus I, III, V, dan VI dan tidak pernah memberikan nafkah sama sekali kepada anaknya setelah perceraian terjadi terdapat pada kasus IV sedangkan pada kasus II terbagi menjadi dua yaitu, Nafkah anak pertama dari hasil pernikahannya yang pertama masih terpenuhi dan Nafkah anak yang kedua dari hasil pernikahan yang kedua tidak diberikan lagi karena hasil dari pernikahan siri dan ibunya juga telah menikah lagi.

\footnotetext{
${ }^{40}$ Wahbah az-Zuhaili, Fiqih Sunnah Islam Wa Adillatuhu, 96.

${ }^{41}$ Ibid., 95
} 
Menurut tinjauan hukum Islam, walaupun orang tuanya telah bercerai maka hak nafkah atas anak tidak putus dan tetap menjadi tanggung jawab seorang ayah meskipun ibunya telah menikah lagi karena anak tersebut tetap bernasab kepadanya bukan kepada ayah tirinya. Seorang suami dalam hal memberi nafkah kepada keluarganya merupakan perkara yang wajib. Ayah kandung berkewajiban memberikan jaminan nafkah kepada anak kandungnya berupa makanan, pakaian, tempat tinggal, dan kebutuhankebutuhan lainnya. Orang yang paling dekat dengan anak adalah ayah dan ibunya, apabila ibu bertanggung jawab atas pengasuhan anak di rumah maka ayah bertanggung jawab mencarikan nafkah anaknya. Pihak ayah hanya berkewajiban menafkahi anak kandungnya selama anak kandungnya dalam keadaan membutuhkan nafkah. Memberi nafkah hukumnya wajib, seorang ayah jika tidak memberi nafkah kepada anaknya, berarti telah melanggar perintah Allah. 


\section{DAFTAR PUSTAKA}

Al-hajjaj, Abu al-Husaini al-Qusyairi an-Naisaburi Muslim. Sahih Muslim.

Beirut: Dar Ihya at-Turats al-Araby, tt.

Al-Khauli, Bahay. Islam dan Persoalan Wanita Modern. Solo: CV. Ramadhani, 1988

Alu Syaikh, Abdullah bin Muhammad bin Abdurrahman. Tafsir Ibnu Katsir,

Terj, M. Abdul Ghoffar. Jakarta: Pustaka Imam Asy-syafi'I, 2008.

As-Subki, Yusuf Ali. Fikih Keluarga. Jakarta: Amzah, 2010.

Az-Zuhaili, Wahbah, Fiqih ssusunnah Islam Wa Adillatuhu. jilid 10. diterjemahkan oleh. Abdul Hayyie al-Kattani, et.al., Jakarta: Gema Insani, 2011.

Az-Zuhaili, Wahbah, Fiqih ssusunnah Islam Wa Adillatuhu. jilid 10. diterjemahkan oleh. Abdul Hayyie al-Kattani, et.al., Jakarta: Gema Insani, 2011.

Jabir al-Jaza'iri, Abu Bakar. Minhajul Muslim, diterjemahkan oleh Kholif Mutaqin. Jakarta: Darul Haq, 2006.

Mathlub, Abdul Majid Mahmud. Panduan Hukum Keluarga Sakinah. Surakarta: Era Intermedia, 2005.

Muhammad, Abi Abdullah ibnu Ismail al-Bukhari. al-Jami' Ashih, Juz III. Qohirah: al-Maktabah as-Salafiyyah, $1400 \mathrm{H}$.

Quthb, Sayyid. Tafsir Fi Zhilalil Qur'an. jilid 1. Jakarta: Gema Insani, 2005.

Sulastiningsih. Cerdas Mengelolah Keuangan Keluarga. Yogyakarta: Pro-U Media, 2008.

Takariawan, Cahyadi. Di Jalan Dakwah Aku Menikah. Solo: Era Intermedia, 2006

Tihami, dan Sohari Sahrani. Fikih Munakahat. Jakarta: Rajawali Pers, 2013

Tim Penyusun. Kamus Besar Bahasa Indonesia. Jakarta: Pusat Bahasa, 2008.

Thalib, Muhammad. Ketentuan Nafkah Istri dan Anak. Bandung: Irsyad Baitus Salam, 2000.

Undang-Undang Kompilasi Hukum Islam. Bandung: Fokusindo Mandiri, 2013.

Washil, Muhammad. Nashr Farid dan Abdul Aziz Muhammad Azzam. Qawaid Fiqhiyyah, Jakarta: Amzah, 2009. 